\title{
Reflection
}

\section{Understanding the encounter between Africa and the West in a profound way}

\author{
VAN DER WALT, B.J. 2003. Understanding and rebuilding \\ Africa; from desperation today towards expectation for \\ tomorrow. Potchefstroom : Institute of Contemporary Christianity in \\ Africa. 553 p. Price: R150. ISBN: 1-86822-419-8.
}

Reviewer: L. Nyirongo

(Insight Consulting, Kitwe, Zambia)

Although I have never met Prof. Van der Walt, the author of the above-mentioned book in person, I came to "know" him during the late 80 s by reading many of his books. The late 80 s was a time when politicians were challenging the ideologies of communism, socialism and humanism and the "free-market" ideology was welcomed back. My interest in die approach of Van der Walt was fuelled by the emphasis he used, that is understanding and interpreting the world in the light of Scripture.

The above-mentioned publication of Van der Walt is a continuation of this angle of approach.

The theme of "understanding Africa ..."

Africa is a bleeding continent because of one reason - a lack of understanding. By "understanding" Van der Walt does not mean man-made understanding; he means God-inspired understanding. This understanding begins with the repentance and confession of Christ as Saviour and Lord of all areas of life - political, economic, social, cultural, academic, etc.

This is the foundation of Understanding and rebuilding Africa. Throughout the book the author puts issues in this context. If we really hunger to do God's will for this great continent, we will receive 
blessings from the Lord. If we do our own thing, trusting our own wisdom, we will get worse and worse - and then perish. For lack of understanding people perish, not just physically but also intellectually, socially, economically, politically, culturally, and worst of all - spiritually.

\section{First understanding, then action}

The author does not end at urging readers to understand the root causes of Africa's crisis, but goes further to suggest practical Biblebased solutions. If Christ is the source of our understanding, then we are compelled to do what He commands us to do. In Africa activists or "liberators" of all kinds are zealous to solve our social and economic problems, but all of them have failed. They have failed because they use deficient solutions, based on a deficient mindset.

My commentary on this book is in the form of flashes aimed at stimulating the reader's interest in the book which I regard as a Bible-rooted practical guide.

\section{Flashes from the different chapters}

\section{Chapter 1: The impact of slavery, colonialism, neo-colonialism and Christianity}

At the outset the author gives us an historical background. If one does not know the history of Africa, one's understanding of the continent is already deficient. Slavery, colonialism, neo-colonialism and Christianity as presented to our continent by the white man resulted in an invasion of our culture by a more forceful culture. The author is careful to point out not just the bad things associated with this invasion - a mistake which many African writers and politicians have made - but also the good things, such as formal education, medicine, development of a limited infrastructure, individual progress (as opposed to extreme communalism, typical of African communities), formation of states (as opposed to tribal groups which fought frequently) and - most important of all - Christianity (which has brought spiritual transformation to many Africans, causing them to abandon pagan worship which blinded them).

As a result of the invasion, Africa also experienced bad things, such as racism, exploitation, fuelling of tribal rivalries, undermining of traditional authority patterns, destruction of African culture, etc. Because of the white man's misguided view of the African, he 
perceived the African as not only inferior to the white man, but also primitive. The black man needed the white man to "develop" or liberate him from his primitive state. In many cases, even the Bible was used to justify the injustices done to Africans.

As a result of this perception the full Gospel was not preached. The full Gospel, as the author emphasizes, knows no discrimination. All men and women, regardless of their economic, social or cultural status, are equal before God and have the same sinful nature. If the white man had come to Africa with this understanding (and willingness to learn from the African who was also created in the image of God), none of the above injustices would have been practised. The white man's deficient understanding was evidenced by the following outlook in his interaction with the African (p. 26-28):

- The emphasis on individualism (autonomous man), ignoring the fact that man is also a communal being.

- The confusing of the Gospel with Western civilization.

- The wholesale rejection of the African's traditional culture. Westerners could not appreciate the fact that God created a variety of races, with distinct traditions and customs.

- The secularization of public life and the privatization of religious life. The state and religion are considered to be totally separate entities.

The impact of this outlook on Africans was so strong that when they gained independence they could not simply shake it off. In many areas "independent" African nations developed a dependency syndrome. For example, political structures were either French, British, German or American. Later African politicians tried several brands of socialism only to make matters worse. In the other areas, such as educational, legal, technological or business systems, the syndrome has continued.

This dependency syndrome seems to be more evident in Christianity. No genuine Christian can argue that the Gospel message must be the same everywhere in the world. To insist that Africans should exactly copy the Western way of worship, e.g. hymns, style of preaching or praying, is to look down on God's variety in creation.

\section{Chapter 2: The contemporary crisis in Africa}

After laying down a historical foundation, the author discusses the root causes of Africa's social, political, economic and leadership 
crises. In Africa we see growing poverty, hunger, diseases, injustices, wars and political confusion. The author discusses the different causes: bad government, the international economic system (which is dominated or controlled by the West), bad management, lack of education, declining morality, lack of appropriate science and technology, population growth, a deteriorating environment, incompetent leadership, corruption, tribalism, religious intolerance, a wrong type of Christianity and the AIDS pandemic.

The author is not pessimistic. He ends the chapter with a positive stance: what Africa ought to be. He encourages us to take charge of Africa (do not allow the West to dictate your economies); get organized (African governments must be transparent and accountable to their citizens) and follow and do the will of God (practise what we preach).

\section{Chapter 3: African traditional religion (ATR)}

In this chapter the author gives an exposition of ATR. Africans are generally very religious. Evangelism must therefore not begin with the question whether or not God exists, but rather who this God is. $\mathrm{He}$ is a loving, a holy God, who desires to have a close fellowship with the African. To enjoy fellowship with God, the African must acknowledge that he has sinned against God, repent of his sin and receive Christ as his Saviour and Lord (not seek the ancestors' favour).

\section{Chapter 4: Culture, worldview and religion}

As indicated above, the previous chapter prepares the reader for a comparison between the Western, African and biblical worldviews. Culture is our (African) life in its totality. In this regard our African culture includes, among other things, African religion(s).

Our worldview is the way we perceive reality or life as a whole. This includes the way we view God, norms, man, community, nature, time or history. Just as the culture of one race (or community) differs from that of another race, so also their worldviews differ. Thus our worldview influences the way we develop culturally. The author compares the Westerner's worldview with the African's worldview and then contrasts both with the biblical (Christian) worldview. He then emphasizes that Christianity should transform our worldview and culture. This is because sin distorts the way we think, act or perceive. Only by surrendering our lives to Christ and letting him reveal His will to us are we able to correct our worldviews and transform our cultures. The word transform can also mean renew 
(not merely make better or improve on, as some African theologians have preached).

\section{Chapter 5: African communalism and Western individualism}

The reader should regard this chapter as a detailed contrast between communalism and individualism. The two are extremes. African communalism underplays the importance of the individual in a community but elevates the community. Apart from the community the individual is a nobody. Western individualism is the opposite of African communalism: it makes the individual autonomous and more important than the group. Man can do what he wants without depending on the group's opinion. His self-concept does not depend on belonging to the group. After contrasting the two sides the author gives their negative implications (p. 145-154).

The issue is not a compromise of the two sides, since both are deficient. Only a Christian view of community and individual identity is the answer. Man is an individual, with a unique purpose, gifts and talents and is accountable to God and fellowman as an individual. But man is also a social being. He needs others to fulfil God's will for his life. Man does not only glorify God as an individual, but also as a member of the community in marriage, family, church, state, company, etc.

\section{Chapter 6: Traditional African and modern Western concepts of time}

The way we use time can tell whether or not we have a right relationship with God. This is because God is the originator, controller, perpetuator and terminator of our time.

The author does not favour the Western view of time (time is money, it can be bought and sold like a commodity), neither does he favour the African's view of time (time can be stretched, increased or paused). The implications for the West are: worship of efficiency and speed as well as competition. One always has to be in a hurry to get things done; waiting is dangerous. In the case of Africa, the idea that time is always waiting for you has contributed to sloth, underdevelopment and loss of opportunities.

The answer to the two extremes lies in understanding God's view of time. Time is a gift from God and as such we must use it carefully and also listen to what God wants us to do at specific times. As stewards of His time we are accountable to Him how we use it. Sometimes God tells us to wait and listen for further instruction; at 
times He wants us to move on; at other times to rest and worship Him.

\section{Chapter 7: The African way of thinking compared to the Western mode of thought}

In this chapter the author argues that the African mode of thinking is not inferior to the Western way of thinking; it is just that Africans think differently. In other words, the African's thinking is not primitive and that of the Westerner not cleverer or superior.

To argue his case he compares 30 features of the African mode of thought with those of the Western (scientific) mode (pages 187-188) and concludes that both sides need each other. "To my mind the holistic picture which African thought offers is as important as the detailed (analytical, scientific) knowledge of Western science" (p. 195).

This is one reason why the West needs to understand the African's way of thinking before implementing any developmental projects or selling their democracy or free-market ideology.

\section{Chapter 8: Different schools of philosophy in Africa}

In this chapter the author argues that Africans, even before being colonized, developed a philosophy of their own and passed it on to the younger generation. They may not have written it down systematically in the form of text books, but it was philosophy nonetheless.

Before colonialism, much of African philosophy may be called ethnophilosophy and sage philosophy (which dealt with the tribal or community past). During the rise of colonialism and imperialism (preceded by slave trade), African political leaders preached and wrote their own philosophies as a reaction to the burden of colonialism and imperialism (therefore they are called reactionary/ liberation philosophers). Examples are Kaunda's Humanism, Nyerere's Ujamaa and Senghor's Negritude. African professional philosophers (with Ph.D.s) emerged recently. However, these do not appreciate the other groups of philosophers because they consider them as unsystematic and confined to the African situation. They prefer universally accepted philosophies. The author cautions such attitudes and urges the professional philosophers to have a positive interaction with the former types of philosophies in order to create a philosophy that is relevant to Africa. 


\section{Chapter 9: Morality in Africa today - a serious crisis}

It is interesting to note that the virtues taught in African traditional communities are also mentioned in the Bible, e.g. humility, hospitality, honesty, respect, peace, forgiveness, justice, endurance, patience, etc. Bad qualities, such as jealousy, envy, adultery, stealing, hatred, anger, etc. denounced by the Bible are also denounced in the traditional community. Why then do we have such a serious moral crisis on the African continent?

After listing down the African virtues the author evaluates them in the light of the spirit governing them. The spirit is not biblical but pagan. The African traditional morality, argues the author, is communalistic, humanistic, pragmatic, utilitarian, tribalistic and thisworldly (p. 220-225). In short it is man-centred, passed on from the ancestors and implemented by the community.

The solution to our moral crisis does not therefore lie in embracing African or Western values, but in genuine repentance and faith in Christ and learning and practising biblical norms at personal, marriage, family, church and school level.

\section{Chapter 10: The sacralization and desacralisation of authority and power}

Being community-centred rather than God-centred, African traditional communities tend to make their ancestors, chiefs, kings, queens, and spiritual leaders (diviners and medicine men) divine. God is far away and can only be approached via the community leaders who play the role of intermediaries. Even today Africans worship their leaders (they create personality cults). With the coming of Western democracy (with its secular view of office and authority) Africans also seem to be going to the other extreme: disrespect of authority.

The Bible does not encourage worship of office and authority nor of leaders in authority. It encourages respect and honour for government authorities and to pray for them to provide wise and just leadership. The Bible also encourages us to obey government laws as long as such laws are in tune with God's norms given in the Bible.

The author also challenges the belief that office and authority are the privilege of the few (the rest of the people are merely followers). The Bible recognizes not just state authority, but also enterprise authority, church authority, family authority, club authority etc. All 
these societal relationships should check one another's practices to ensure that each is obedient to God. No office or societal relationship should dominate the other.

\section{Chapter 11: Religion and politics}

In this chapter the author challenges the prevailing belief that the state and religion should be separate, meaning that Christians should not involve themselves in politics or should not even aspire for political positions. Their witness should be private and personal. Politics belongs to the secular, public realm; the church to the spiritual, private realm.

According to the author, the state (the government plus the citizens) is one of the societal relationships which ought to be influenced by the Gospel. Of all the societal relations only the church has been mandated by God to go out and make disciples of all nations. This implies that the Gospel will affect the way politics and government should be conducted. But although the church is expected to influence all societal relationships, she has not been mandated to take up the role of the state. The state's role is to execute public order, public peace and justice so that the other societal relationships can carry out their God-given mandates in a peaceful environment. If a Christian wants to get involved in politics, his desire should be to influence the state to obey God in carrying out its specific mandate, not to influence the church to take over the role of the state. On the other hand, if the head of state becomes a Christian, he is not expected to influence the state to take over the role of the church, but to influence the state to obey God.

\section{Chapter 12: Human rights - a serious (Christian) duty}

The author wants us to understand human rights (e.g. the right to good education, right to justice, right to good health, right to decent shelter etc.) in a biblical context and thus to avoid being misled by the so-called human rights activists.

Bad politics, bad governance, corruption and sheer mismanagement of public funds cause some of our social and economic problems. Other problems may be self-imposed, such as child abuse, alcohol/drug abuse, divorce, ignorance, laziness etc. God commands us to do what we can to help solve some of these problems. From this perspective, human rights are not man's idea, but God's. 
Human rights outside the biblical context, however, have tended to be characterized by:

- An emphasis on individual rights (the "me" generation), forgetting that what the individual wants can be detrimental to the entire community.

- A legalistic attitude, solving conflicts strictly to the letter of the law, which may also be oppressive (as in the case of the Pharisaic system). Retaliation becomes more important than love and forgiveness. Sometimes we may have to give up our individual rights for the sake of our brother/sister.

- A neglect of personal and communal responsibilities, emphasis on what I or we want, not what part I am or we are supposed to play.

- A promotion of secularization. Every individual has the right to choose and practise his own religion as a private or personal pursuit. The public sector is secular.

- An undermining of real justice. Too much emphasis on human rights may subordinate or weaken justice.

\section{Chapter 13: Five requirements for reconciliation}

The central message of this chapter is that to achieve real reconciliation between parties, four conditions must be met: Acceptance of responsibility for the wrong done (at group or individual level); repentance and conversion (at group or individual level); confession of wrong-doing to God and the people; setting right the injustice - which should lead to real reconciliation.

\section{Chapter 14: Religious diversity, equality, freedom and tolerance}

The author argues that despite the prediction of increasing, widespread secularism, there is instead a revival of various kinds of religious awareness. "On the one hand", writes Van der Walt, "it would seem as if we are living in a post-religious world, but on the other hand there is a large-scale resurgence of religious awareness. On the one hand there is less god (he has been declared dead) and on the other hand more god, or everything is god: god in nature, in oneself, in one's fellowman, in other religions, everywhere!" (p. 379).

By religious diversity the author does not imply that we should accept or embrace all religions. Christianity - if faithfully interpreted, preached and practised - draws people by love, not by force. People must willingly repent and receive Christ as Saviour and Lord. 
By religious tolerance the author does not mean we should compromise our Christian faith or regard other religions as harmless. We must reject false teaching (defensive strategy) but at the same time preach the truth (offensive strategy).

\section{Chapter 15: Corruption: a many-headed monster}

This chapter describes the anatomy of corruption in Africa. In many African nations, corruption has spread to all sectors of the economy. Van der Walt's description also includes political corruption, such as vote rigging and the transferring of public funds into personal accounts.

After describing types of corruption the author then describes wrong reactions to corruption, root causes and biblical solutions. Corruption is a spiritual problem and the basic solution must be a change of heart.

\section{Chapter 16: Stewardship of our natural environment}

Living a fully Christian life also implies good stewardship, appreciation and enjoyment of our natural environment. Christians should therefore be in the forefront to advocate the protection, preservation and development of our natural environment. If we do not care for our environment we will fail to glorify God in other instances as well. God created the environment in such a way as to ensure the balance, stability and well-being of nature. Salvation should result in our good stewardship of the environment in obedience to God's mandate.

The author also cautions us to be careful lest we deify nature (turn nature into a god). The wonders of nature can replace the worship of the true God. If even nature is said to praise God (Ps. 19:1-3), it would be foolish to pay homage to nature.

\section{Chapter 17: Development of the African continent}

The author argues that development is not a one-dimensional word (industrialization, as the West has made us believe). The author defines development in the light of our God-given mandate. After weighing all the existing models of development (and finding them wanting), the author suggests the following definition of development:

Development is the (1) balanced unfolding of (2) all the abilities of the human being and (3) the potential of material things, plants and animals, (4) according to God's purpose and (5) His will, to 
enable the human being (6) within his/her own culture (7) to fulfil his/her calling (8) as a responsible steward of creation (9) in a free society (10) to the honour and glory of God. (p. 450).

This definition cannot be appreciated by Westeners who have an individualistic, capitalistic, materialistic worldview.

\section{Chapter 18: Towards normative economy}

In this chapter the author provides a deeper understanding of economic development. He argues that unless Africa embraces biblical norms for economic (business) life, it will continue to experience poverty and to suffer from the dependence syndrome.

Unlike Adam Smith's free-market ideology (that God created the world like a clock and left it to humans to use as they wish), the Bible speaks of God being interested and involved in the economic life of nations and individuals. Economic blessings will depend on discovering and obeying God's norms for business and life in general.

\section{Chapter 19: The African Renaissance: New hope for the future}

The purpose of this chapter is threefold:

- To determine the character of both the earlier European Renaissance (from approximately 1300-1600) and that of the contemporary African Renaissance which is currently taking shape;

- to look for similarities and differences between the two movements;

- in the light of the results of the previous two points, to formulate a Christian response to the present African Renaissance .

Chapter 20: An integral Biblical worldview: a key to the rebuilding of Africa

In this last chapter the author summarises his view of how Africa can be saved from the prevailing crisis and concludes that Africa can be saved by applying an integral biblical worldview.

First he traces the historical background of dualistic thinking. Precolonial, colonial and post-colonial evangelization gave birth to a dualistic worldview among Africans. What is a dualistic worldview? Where did it originate? How did it spread to Africa? What are its negative implications on Christian witness and on African progress 
and development? The author deals with all these questions in this concluding chapter.

A dualistic worldview is a kind of thinking among Christians which separates secular life from religious life. In practice, however, the secular (worldview) becomes so influential that the spiritual side is subordinated to the secular (making the religious life a handmaid of secular life). With regard to Christianity, the church has to be separated from politics or business matters.

The implication of such a dualistic thinking is that it becomes difficult for Christians to be true witnesses in all sectors of life. Christ's commission to make disciples of all nations becomes a dilemma: how can I make my Christian life meaningful and relevant to the public (secular) as well as to private life?

The author gives the following types of dualistic thinking, which makes Christian witness in all areas of life a dilemma:

- Christ against culture - to be against the world or withdraw from the world. This viewpoint has resulted in living a private Christian life or a Christian life that is anti-anything that is not run by Christians. But Christ said we should live our Christian life in the world (be salt or light). At the same we must not be part of the (sinful) world.

- Christ of culture. This viewpoint has resulted in humanism: grace equals nature, that is, man's rational thinking is as good as or can replace God's grace.

- Christ above culture, that is grace simply perfects nature (Roman Catholic theology). The essence of this viewpoint is that all we need to do is improve on what we already have. Or we should use what we have as a stepping stone to faith and grace.

- Christ and culture in paradox, that is grace should flank nature. This viewpoint is typical of Lutheran theology.

The author emphasizes the fifth way as the only way that can enable Christians to change Africa. This fifth way is called Christ transforms culture, that is, grace restores culture. We must allow God's grace to work in all areas of life.

Van der Walt is a readable writer and the book is well structured. I strongly recommend this book and hope it will reach a wide reader public. 